\title{
Adapatation of Sowing Date for Improving Sorghum Yield in Rainfed Areas in Sudan Using AQUACROP Model
}

\author{
Mohammed Abd Almahamoud Alshikh ${ }^{1}$, Hassn Ibrahim M. ${ }^{1}$, Salah Abdel Rahman Salih ${ }^{1}$, Ali Hussien Kadhim ${ }^{2}$ \\ \& Khalid Abd Almageed M. ${ }^{3}$ \\ ${ }^{1}$ Department of Agricultural Engineering, Faculty of Agricultural Technology and Fish Science, University of \\ Neelain, Sudan \\ ${ }^{2}$ Engineering College, Sumer University, Iraq \\ ${ }^{3}$ Ministry of Irrigation, Sudan \\ Correspondence: Salah Abdel Rahman Salih, Department of Agricultural Engineering, Faculty of Agricultural \\ Technology and Fish Science, University of Neelain, Sudan. E-mail: salah.55@hotmail.co.uk
}

Received: May 16, 2017

doi:10.5539/jas.v9n8p220
Accepted: June 22, $2017 \quad$ Online Published: July 15, 2017

URL: https://doi.org/10.5539/jas.v9n8p220

\begin{abstract}
Due to the rapid growth in world population, the pressure on water resources to feed the growing population is increasing. The Nile water share of Sudan is almost exploited; and agricultural production by rained water is threatened by the pressure of climate change. It is inevitable that the production per unit water consumed, the water productivity, must be increased to meet this challenge. This research therefore focuses on the benchmarking of physical water productivity in rain fed areas and gaining a better understanding of the temporal and spatial variations and the scope for possible improvement. A review of the available records and sources that provide measurements of crop-water productivity was consulted to assess plausible ranges of water productivity levels for rain fed Sorghum crop and to provide a first explanation for the differences that are found using AQUACROP model. As such this study may be considered as crucial step was to establish a water productivity database for the rain fed sorghum crop in the country. Sorghum (Sorghum bicolor (L.) Moench) which is the most important cereal crop in Sudan has been constrained by the detrimental effect of drought which has often caused food shortages. Almost $90 \%$ of the total sorghum cropped area is rain-fed, and $60 \%$ of that is in drought prone soil conditions. Spatial information on water use, crop production and water productivity will play a vital role for water managers to assess where scarce water resources are wasted and where in a given region the water productivity can be improved. Hence, a methodology has been developed in this study to quantify spatial variation of crop yield, evapotranspiration and water productivity using the AQUACROP model in five stations. The AQUACROP model is used to investigate optimum sowing date that result in maximization of grain yield.
\end{abstract}

Benchmarking of rain fed Sorghum actual and potential grain efficiency in different agro-climate zones was made for the year 1979 to 2013. AQUACROP model was applied at five locations (Gedaref, Damazin, Dalang, El Fashir, and El Obyied) each representing an agro-climate zone. Causes of poor yield performance were investigated and consequently measures needed to improve performance were identified. The study indicates that increase in sorghum yields under historical climate conditions in the different studied stations is possible when early sowing is used and initial rain showers are utilized, yield decrease by $43 \%$ when sowing date is delayed from July 15 (the recommended date) to August 1. Stations with high rain fall (Damazin, Gadaref and Dalang) show little variations in inter-annual yields but with a tendency towards high yields, 3536, 3741, $3737 \mathrm{~kg} / \mathrm{fed}$ for the above stations respectively compared to 2266 and $1086 \mathrm{~kg} / \mathrm{fed}$ for El Obyied and El Fashir respectively at 15 June. The obtained WUE is lower in the driest regions (El Fashir, and El Obyied) and higher for those of high rain fall. To aid decision makers and crop growers in rain fed areas a set of recommendations for policy making and for future research were identified.

Keywords: aqua-crop model, Damazin, Gadaref, Dalang, El Fashir, El Obyied, sowing date, semi-arid areas 


\section{Introduction}

Climate variability has been identified as the major constraint to agricultural productivity in Sudan; and hence reducing the risk associated with climate variability has a high potential for increasing productivity in rain fed areas in the central clay plains of Sudan (Phillips et al., 1998).

Despite contributing a large share of the annual grain output, rain fed production of rain fed sorghum in Sudan is largely unstable (Mhizha, 2010). The fluctuations echo in the availability of food in the country, often with a telling effect on the economy as high financial resources are to be channeled towards securing food to security; which would deprived other economic sectors from development. The instability in rain fed production is largely credited to availability of rainwater, which itself shows wide spatial and temporal variability in both total amounts and distribution.

While agricultural water management has largely succeeded in maximizing rainfall infiltration through soil and water conservation, the challenge of how to cope with dry-spells, short periods of water stress during crop growth, remains largely unsolved (Fox \& Rockström, 2003). This because false planting dates requiring replanting are increasingly common in rain fed areas (Raes et al., 2004), there is an increasing demand for sowing strategies that minimize risk of total crop failure, such as staggered planting (FAO, 1998; Mpande \& Tawanda, 1998), Such sowing strategies need to consider timing and lengths of crop phonological growth stages. This stem from the sensitivity of early growth stages (establishment phase) to increase in rain water and flooding of seedlings. In contrast, flowering stage is sensitive to water shortage where, in water deficient situations crop tends to shed its flowers.

Atmosphere Globally, about $60 \%$ of annual precipitation falling over the land surface isconsumed by ET. Quantification of ET is used formany purposes, including crop production, water resources management, and environmental assessment. In agriculture, accurate quantification of ET is important for effective and efficient irrigation management (Irmak, 2009). The ET data foragricultural crops has become increasingly important in irrigation as well as in water resources management. It is dependent not only on the meteorological elements, but also on factors relatedto the crop, soil environment and management (Abu-Zeid \& Hamdy, 2002).

Keeping view of the above, it is imperative to enhance the water productivity in agriculture. To accomplish this, there are broadly two options such as:

1) Judicious management of rain water resources by determining and staggering sowing date;

2) To improve productivity at the farm level through better management and use of improved varieties having drought resistance and higher yield potential, and

3) To optimize the use of land resources, and rain fed farming technologies.

All this can be achieved by using appropriate tools to predict water productivity under different rain fall amounts and pattern or deficit water supply approaches for different crops.

The complexity of crop responses to water shortage is the use of empirical production functions as the most practical option to assess crop yield response to water. However, most of the current production functions are developed using regression equations or empirical methods and are purely location specific and these black box models have limited applicability to different crops, locations and management practices. Therefore use of physics based crop simulation models were preferred over the regression equations (Steduto et al., 2009).

A crop water productivity model AQUACROP was developed by the Land and Water Division of FAO and released for use during 2009 (Raes et al., 2009). AQUACROP is a model to simulate yield response to water of several herbaceous crops. It is designed to balance simplicity, accuracy and robustness, and is particularly suited to address conditions where water is a key limiting factor in crop production. The AQUACROP model has been parameterized and validated for simulating crops yield response to water (Hsiao et al., 2009; Heng et al., 2009). Although AQUACROP is based on complex crop physiological processes, it uses a relatively small number of explicit and mostly intuitive parameters with simplicity and accuracy (Steduto et al., 2009; Raes et al., 2009). Some of the advantages of AQUACROP are:

1) It is widely applicable with acceptable accuracy;

2) It requires only commonly available input (i.e. climate, soil, and crop and field data);

3) It allows easy verification of simulation results with simple field observations.

Increasing cereal crop yields and productivity to keep pace with vagaries of weather and increased future food demand is thus crucial for enhanced food security, incomes and livelihoods (Chauvin et al., 2012). Production of 
rain fed grain crops is projected to be negatively affected through projected higher and more variable temperatures, changes in rainfall patterns and increased occurrences of extreme events such as droughts and floods (Burke et al., 2006; Cooper et al., 2008). Current crop simulation models can be used to capture and quantify the effects of weather extremes, hence compounding on the already existing uncertainty regarding the direction and magnitude of climate change (White et al., 2011; Ramirez-Villegas et al., 2013) consequently our understanding of the impacts on crops and in the timing of crop adaptation strategies such as adjustments of planting dates and choice of crop cultivars Can be improved.

It is thus crucial to understand the uncertainty surrounding sorghum yield variability, but limited information exist in the clay plains of Sudan regarding the response of existing improved sorghum cultivars towards new climatic futures, considering that sorghum is one of the crops promoted under current climate variability and projected climate change.

Of This study was directed to examine sorghum crop yield response and identify the adaptation options in the sorghum based cropping system using simulation modeling.

The studies concerning sorghum yield in different climatic regions were few and timing of sorghum sowing date was not yet detected. There for this study was conducted with the objective to improve the sorghum yield by set of adaptation options of changes in sowing date using AQUACROP model.

\section{Materials and Methods}

\subsection{The Study Area}

The study was collected from five meteorological stations to represent 5 different agro ecological zones located in the north, middle and south of the country (Tables 1 and 2). Daily Climate Data (Rain fall, humidity, wind speed, sun shine hours, and max and min temperature) and Sorghum crop yield was collected from the five climatic stations (Dalang, Edamazine, Gedarif, El Obyied, and El Fashir) for the period of 1979 to 2013.

Table 1. Characteristics of the stations used in the study

\begin{tabular}{|c|c|c|c|c|c|c|c|c|}
\hline Station & Coordinates & Elevation & $\begin{array}{l}\text { Humidity } \\
(\%)\end{array}$ & $\begin{array}{l}\text { Min. Temp. } \\
\left(\mathrm{C}^{\circ}\right)\end{array}$ & $\begin{array}{l}\text { Max. Temp. } \\
\left(\mathrm{C}^{\circ}\right)\end{array}$ & $\begin{array}{l}\text { Annul Rainfall } \\
(\mathrm{mm})\end{array}$ & $\begin{array}{l}\text { Sunshine Duration } \\
\text { (hours) }\end{array}$ & $\begin{array}{l}\text { Wind Speed } \\
(\mathrm{km} / \mathrm{d})\end{array}$ \\
\hline Dalang & & & 44.1 & 20.8 & 35.3 & 680.6 & 8.3 & 225.3 \\
\hline Gedarif & $\begin{array}{l}14^{\circ} 02^{\prime} \mathrm{N}, 35^{\circ} 23^{\prime} \mathrm{E} / \\
14.033^{\circ} \mathrm{N}, 35.383^{\circ} \mathrm{E}\end{array}$ & $634 \mathrm{~m}$ & 42.4 & 21.4 & 36.8 & 612.0 & 9.1 & 231.7 \\
\hline Edamazine & $\begin{array}{l}11^{\circ} 46^{\prime} \mathrm{N}, 34^{\circ} 21^{\prime} \mathrm{E} / \\
11.767^{\circ} \mathrm{N}, 34.350^{\circ} \mathrm{E}\end{array}$ & $475 \mathrm{~m}$ & 47.7 & 20.7 & 35.8 & 698.2 & 8.1 & 218.8 \\
\hline El Obyied & & & 34.6 & 20.0 & 34.7 & 329.0 & 9.2 & 312.2 \\
\hline El Fashir & & & 31.2 & 17.2 & 34.7 & 193.3 & 9.3 & 180.2 \\
\hline
\end{tabular}

According to Emberger method, Eldmazine belong to the sub-humid class. El-Gedarif is classified as semi-arid and the remaining stations are classified as arid.

The semi-arid zone can be represented by the climate data of El Obyied, Nyala, Abu Naama (Umm Benin) and Gedaref (Figure 1). The dry monsoon zone can be represented by the climate data of Damazin and Kadugli (Figure 1).

Rain-fed agriculture is generally confined to areas where the climate can be categorized as "semi-arid", with mean annual rainfall of $300-600 \mathrm{~mm}$ in the north, and "dry monsoon" with mean rainfall of $600-850 \mathrm{~mm}$ in the south. 


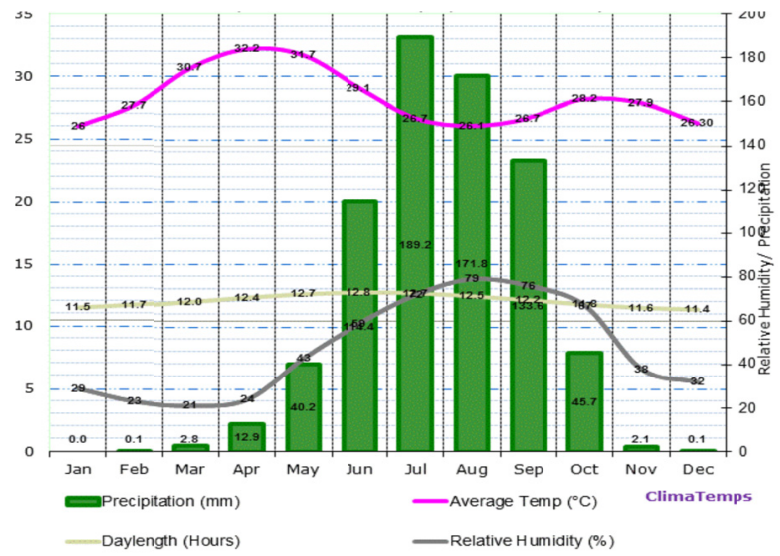

Damazin

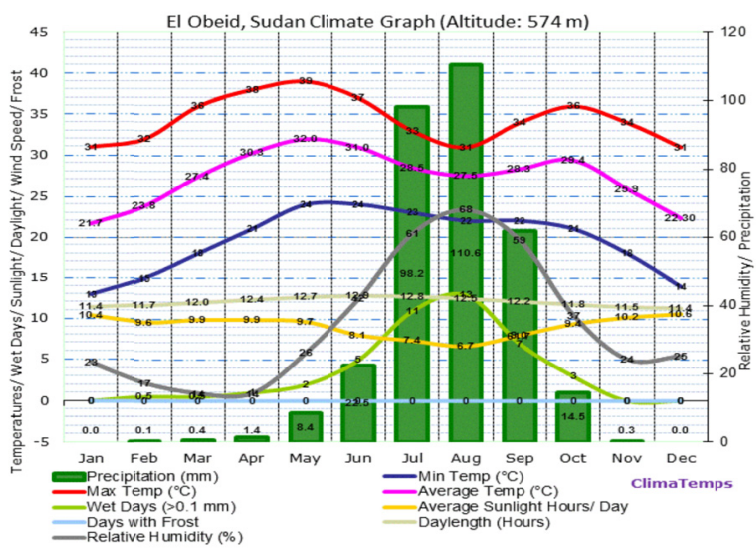

El Obyied

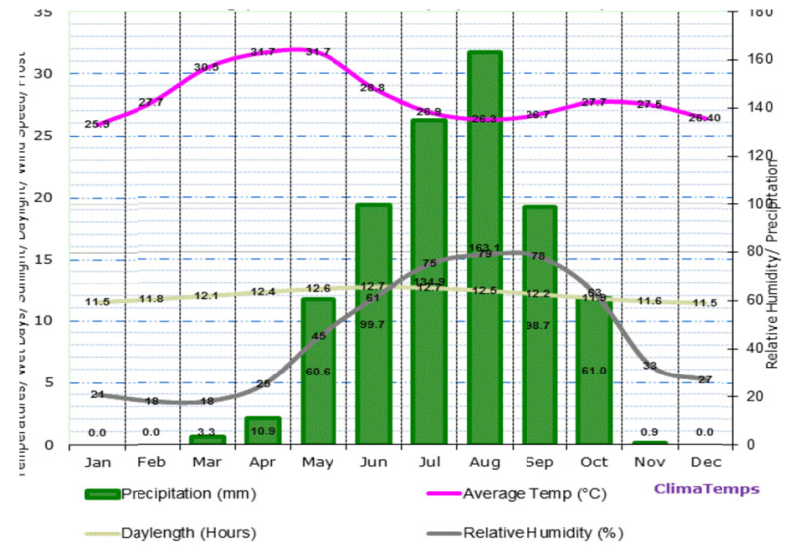

El Dalang

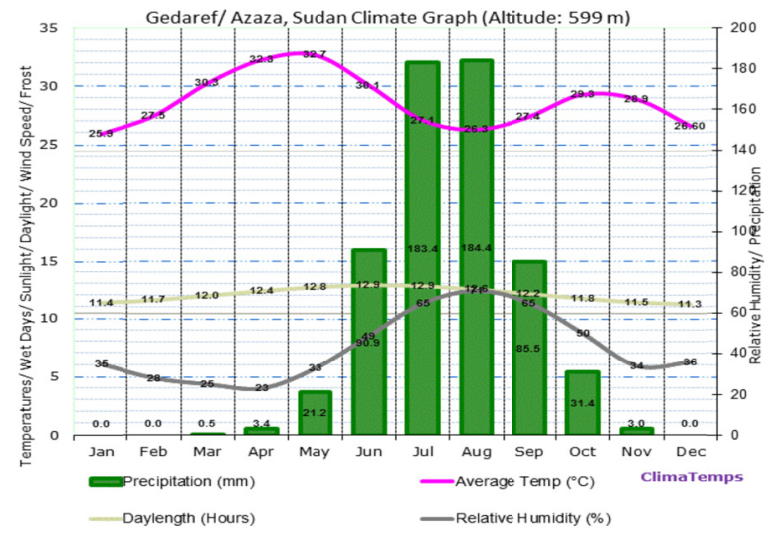

El Fashir

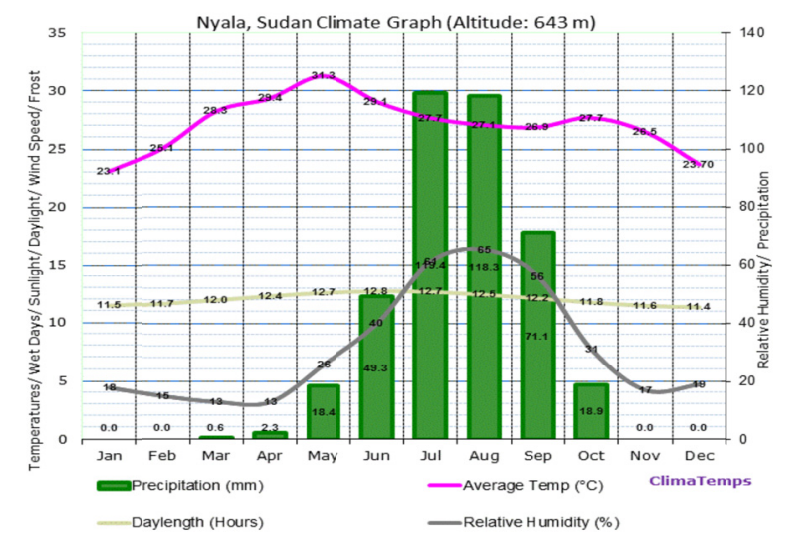

Gedaref

Figure 1. Semi-arid zone - climate data of Damazin and El Dalang El Obyied, Damazin, and Gedaref

\subsection{Types and Sources of Climatic Data}

The climatic variables used were rainfall, air temperature and reference evapotranspiration (ETo). We used observed data as well as downscaled global climate model data (GCM). Observed data was provided by the Sudan Meteorological Services Department (SMSD). For the study, the daily satellite data (air temperature, 
precipitation, wind, and relative humidity have also been downloaded from http://globalweather.tamu.edu website in CSV file format for a given location (South Latitude (12), West Longitude (31), North Latitude (16), East Longitude (34)) and time period, (1/1/1979 to 12/31/2013). The numbers of downloaded weather stations were made for each one of the five cities.

\subsubsection{Input Data}

(1) Model Parameters and Input Data

Weather Data: The weather data required by AQUACROP are the daily values of minimum and maximum air temperature, ETo, rainfall and solar radiation (Raes et al., 2009; Steduto et al., 2009). The standard procedure is to calculate daily reference evapotranspiration (ETo) following the FAO Penman-Monteith equation (Allen et al., 1998).

Soil Data: The required input soil parameters for AQUACROP are the saturated hydraulic conductivity (Ksat), volumetric water content at saturation $(\theta$ sat), field capacity $(\theta \mathrm{FC})$, and permanent wilting point $(\theta \mathrm{PWP})$. These parameters were derived from field measurements.

Crop Yield Data: During the 1979-2013 seasons, actual field reported yield data was collected from the data bank of Federal Ministry of Agriculture for Sorghum crop in each one of the 5 cities.

AQUACROP requires identifying generic growth stages of time to emergence, maximum canopy cover, start of senescence, and maturity. For the purpose of AQUACROP simulation, time to emergence, maximum canopy cover, and start of senescence were based on field observations.

\subsubsection{Input Data Requirement of AQUACROP Model}

(1) Environment and Crop Data

(A) Climate: (i) Daily/10 days/monthly rainfall; (ii) Daily/10 days/monthly ETo; (iii) Daily/10 days/monthly temperature; (iv) $\mathrm{CO}_{2}$ concentration.

(B) Crop: (i) limited set (crop development and production parameter which include phonology and life cycle length). (ii) Full or all crop parameters: a) Crop development at no water, fertility and salinity stress; b) Evapotranspiration; c) Crop water productivity; d) Water stresses; e) Air temperature stresses; f) Soil salinity stress; g) Effect of soil fertility stress; h) Calendar of growing cycle.

(C) Management: (i) irrigation type; (ii) Field Mulches Field surface practices; (iii) Surface runoff.

(D) Characteristics of soil horizon (no. of soil horizon, thickness, PWP, FC, SAT, Ksat): (i) Soil profile; (ii) Soil surface (runoff, evaporation) restrictive soil layer capillary rise; (iii) Ground water (constant or varying depth and water quality).

(2) Simulation Data

(i) Simulation period (linked to growing season); (ii) Initial condition: Initial soil water content, soil layer thickness, soil salinity (specified for specific layer).

All these input data were used in the model to predict the yield, water productivity, and harvest index of a given crop. However, the model should be calibrated and validated using the data acquired from field experiments for its further use.

\subsection{Data Analysis: AQUACROP Yield Prediction Model}

AQUACROP is a crop water productivity model developed by the Land and Water Division of the Food and Agricultural Organization (FAO) (Raes et al., 2009). It simulates yield response to water of herbaceous crops and is particularly suited to address conditions where water is a key limiting factor in crop production (FAO, 2009). The model does not take into consideration such factors like pests, diseases and weeds. AQUACROP requires the following input data: daily weather data (air temperature, reference evapotranspiration and rainfall), soil texture data (sand, clay, loam, in \%) and crop parameters (initial, final and rate of change in \%; canopy cover; initial, final and rate of deepening in root depth; biomass water productivity; harvest index; typical management conditions such as irrigation dates and amounts, sowing and harvest dates, mulching, etc). If daily climatic data is not available, 10-day and monthly data can be used as input. Details of the crop model that include: phenology, growth and water balance are contained in FAO (2009). 


\section{Results and Discussions}

\subsection{Determining the Optimal Planting Date}

Adjustment of sowing dates for sorghum as one of the adaptations in future climate change scenarios was tested in the modeling framework through shifting by either bringing forward or delaying sowing within a regular interval (Do-15, Do+15 days) with respect to the baseline case, Do being the normal sowing date. Results from the adjustments are shown in Figure 2 indicate increase in sorghum yields under historical climate when early sowing is considered in almost all stations. Decrease in yield with late sowing may be due to incidence of low early rains (rains coming late). In stations with high rains (Dalang, Damazin and Gadaref) it is preferred to sow early to benefit from the probable early rains. These results are in agreement with Rinaldi (2004), Heng et al. (2007), and Asseng et al. (2008) who used AQUACROP to determine the optimal sowing date in relation to initial soil water to maximize wheat grain yields.

Figure 3 indicate that there is however a trend towards higher inter-annual variability, i.e. more years with high or low yields. Stations with high rain fall (Damazin, Gadaref and Dalang) show little variations in inter-annual yields but with a tendency towards high yields. Contrastingly, El Obyied and El Fashir show wide variations in yields and a trend towards lower yields. These results seem to suggest that depending on the onset of rain fall, adapting sowing dates may be effective in counteracting adverse climatic effects as shown by the slight increases in median yields compared to yields from baseline. However the erratic nature of rainfall, characteristic of semi-arid areas (which unfortunately cannot be captured by the model) tend to shorten the planting window, such that a delay of two weeks in sowing may cause significant reduction in yields due to shortening of the length of growing period (yield decrease by $43 \%$ when sowing date is delayed from 15-July (the recommended date by ARC) to 1st of August. This may be due to effects of initial soil water stored from onset of early summer rainfall can influence early establishment of the crop and can contribute to water use and yield later in the season, in particularly in low rainfall seasons. Table 2 shows the average Potential model yield for the different sowing dates for each one of the five stations ( $\mathrm{kg} / \mathrm{fed})$. It is evident from the table that the date with maximum yield for El Obyied, El Dmazin, El Fasher, El Gadaref, and El Dalang are 1-July, 15-June, 15-July, 15-June, and 15-June respectively.

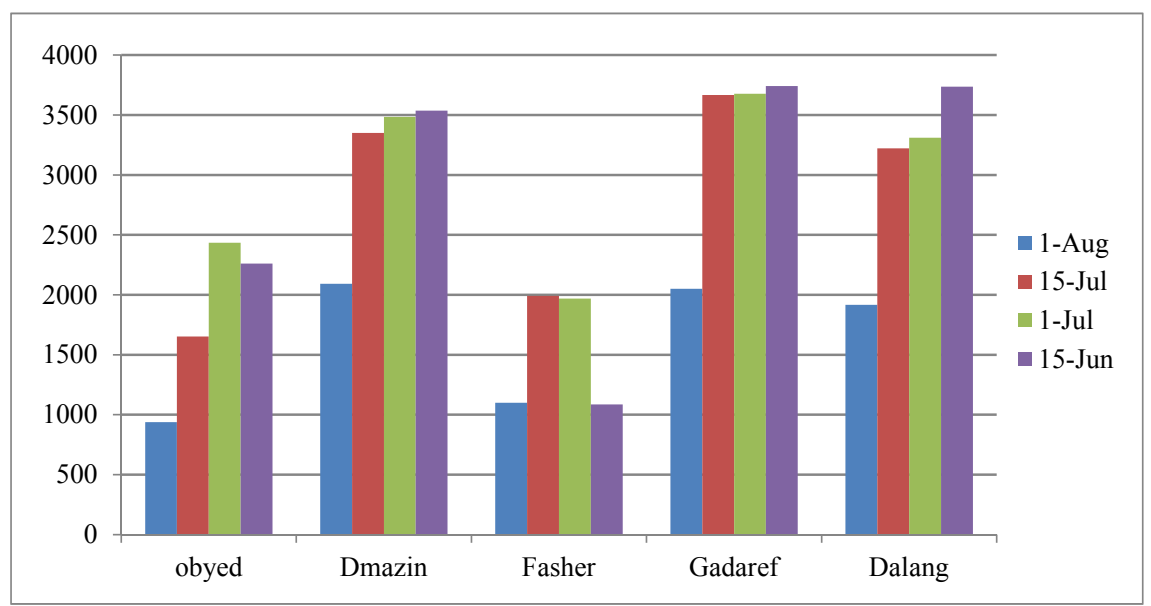

Figure 2. Sorghum grain yield due to changes in sowing dates in the different stations

Table 2. Average potential model yield for the different sowing dates for each one of the five stations $(\mathrm{kg} / \mathrm{fed})$

\begin{tabular}{lllll}
\hline Station & 15-Jun & 1-Jul & 15-Jul & 1-Aug \\
\hline El Obyied & 2266 & 2435 & 1652 & 938 \\
El Dmazin & 3536 & 3485 & 3350 & 2092 \\
El Fasher & 1086 & 1969 & 1992 & 1100 \\
El Gadaref & 3741 & 3677 & 3667 & 2051 \\
El Dalang & 3737 & 3311 & 3222 & 1917 \\
\hline
\end{tabular}




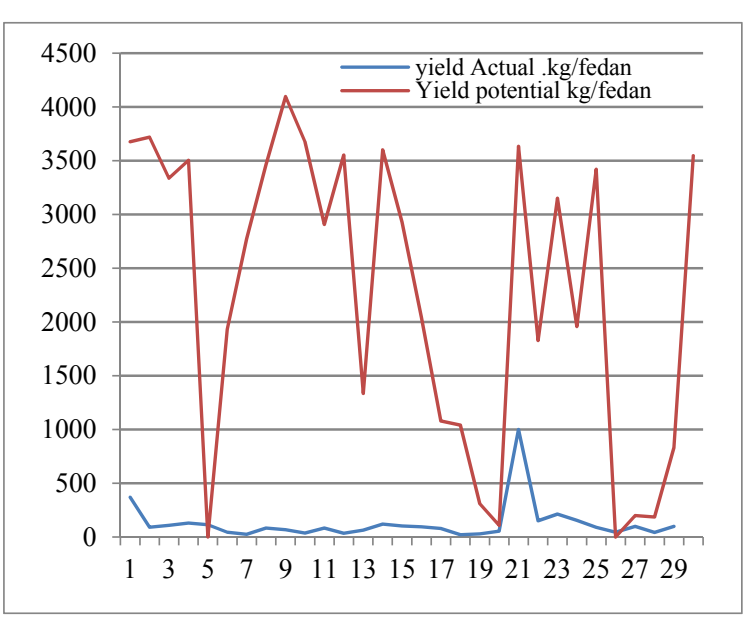

(A) El Obyied

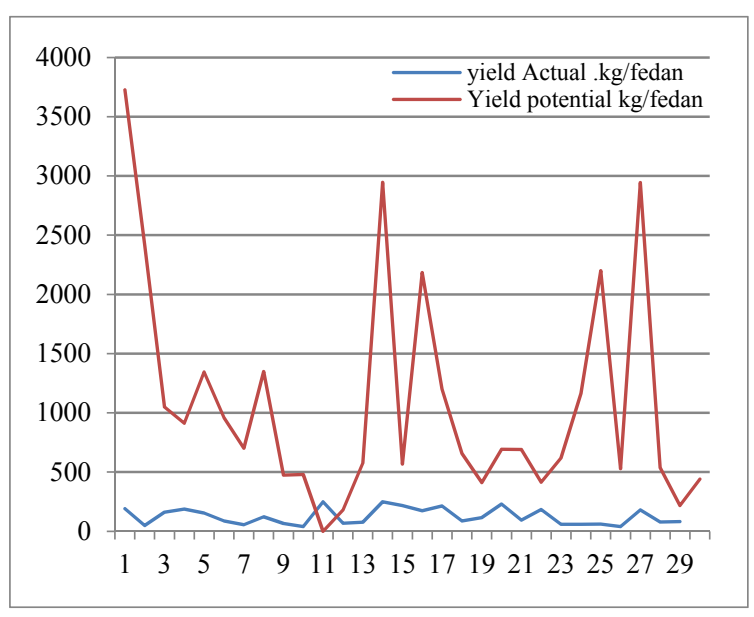

(C) El Fashir

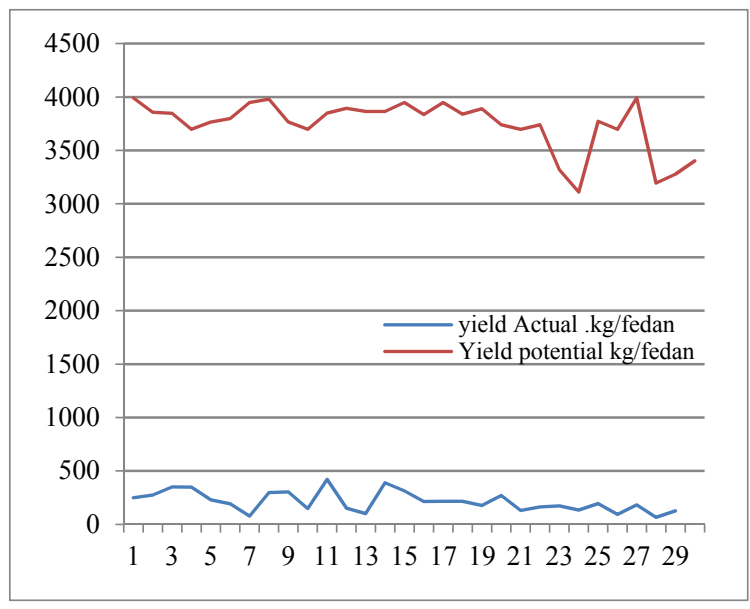

(B) El Gadaref

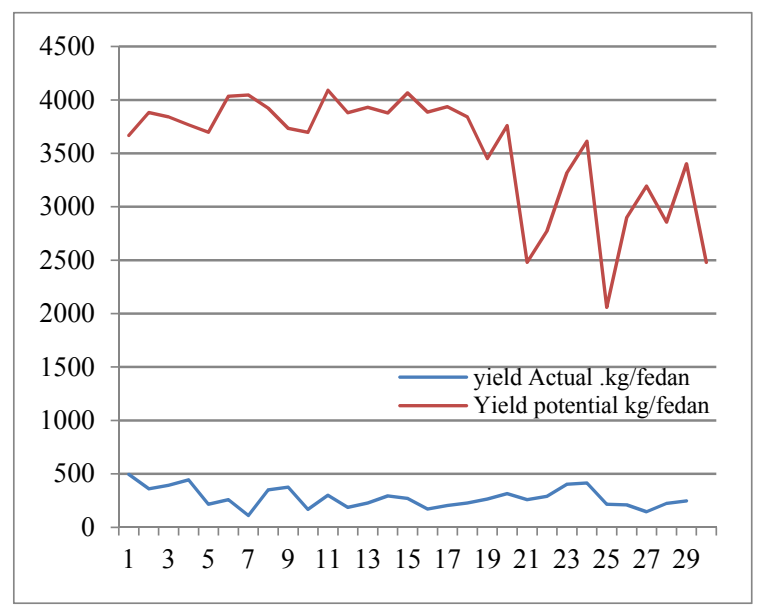

(D) El Damazin

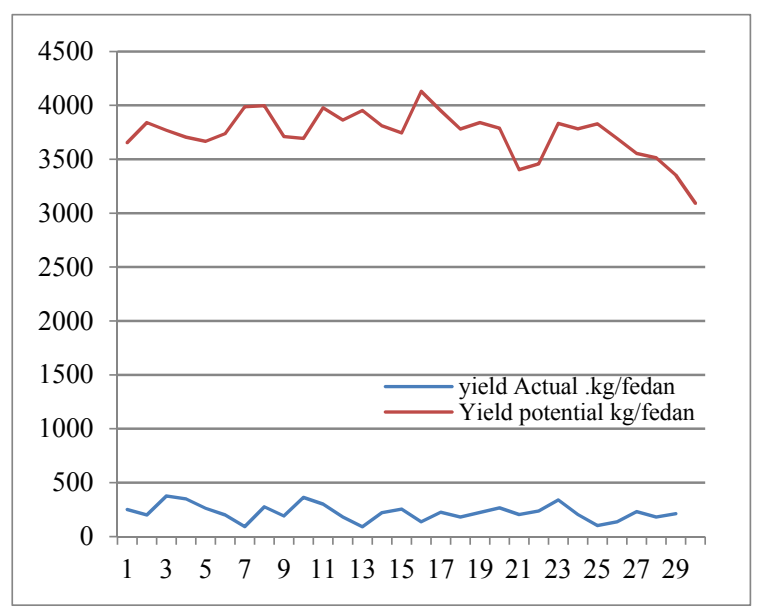

(E) El Dalang

Figure 3. Inter-annual variability, of crop yield in each station $(\mathrm{kg} / \mathrm{fed})$

\section{Conclusions and Recommendations}

Study of Benchmarking yield gaps in rain fed agriculture and assessment of long-term productivity in rain fed agriculture in Sudan indicate that: 
(1) The farmers' choice of sowing date can be an important adaptation strategy to climate change and this management options should be considered in climate change impact studies on agriculture.

(2) There is potential to increase farm productivity by better exploitation of the scarce water in the dry season. It may be possible to increase farm incomes significantly by growing high value short-duration crop cultivars through improving water utilization efficiency by early crop planting to better use of early season soil water.

\section{References}

Abu-Zeid, M., \& Hamdy, A. (2002). Water vision for the twenty-first century in the Arab World. Draft document, a report on World Water Council $3{ }^{\text {rd }}$ World Water Forum, Cairo, Egypt.

Adam, H. S. (2015). Climate Change and Irrigation in Sudan. Sudan Academy of Sciences Journal, 11(Special Issue), 115-117.

Allen, R. G., Pereira, L. S., Raes, D., \& Smith, M. (1998). Crop evapotranspiration: Guidelines for computing crop water requirements. Irrigation and Drainage Paper No. 56 (p. 300). FAO, Rome, Italy.

Asseng, S., Foster, I., \& Turner, N. C. (2011). The impact of temperature variability on wheat yields. Global Change Biology, 17(2), 997-1012. https://doi.org/10.1111/j.1365-2486.2010.02262.x

Burke, E. J., Brown, S. J., \& Christidis, N. (2006). Modeling the recent evolution of global drought and projections for the twenty-first century with the Hadley Centre Climate Model. Journal of Hydrometeorology, 7, 1113-1125. https://doi.org/10.1175/JHM544.1

Chauvin, N. D., Mulangu, F., \& Porto, G. (2012). Food production and consumption trends in Sub-Saharan Africa: Prospects for the transformation of the agricultural sector. Working Paper No. 2012/011 (p. 76). United Nations Development Program. Regional Bureau for Africa.

Cooper, P. J. M., Dimes, J., Rao, K. P. C., Shapiro, B., Shiferawa, B., \& Twomlow, S. (2008). Coping better with current climatic variability in the rain-fed farming systems of sub-Saharan Africa: An essential first step in adapting to future climate change? Agriculture, Ecosystems and Environment, 126, 24-35. https://doi.org/ 10.1016/j.agee.2008.01.007

Fox, P., \& Rockström, J. (2003). Supplemental irrigation for dry spell mitigation of rainfed agriculture in the Sahel. Agric. Water Manage., 61, 29-50. https://doi.org/10.1016/S0378-3774(03)00008-8

Heng, L. K., Hsiao, T. C., Evett, S., Howell, T., \& Steduto, P. (2009). Validating the FAO AquaCrop Model for Irrigated and Water Deficient Field Maize. Agron. J., 101, 488-498. https://doi.org/10.2134/agronj2008. 0029xs

Hsiao, T. C., Heng, L. K., Steduto, P., Rojas-Lara, B., Raes, D., \& Fereres, E. (2009). AQUACROP-The FAO crop model to simulate yield response to water: III. Parameterization and testing for maize. Agron. J., 101, 448-459. https://doi.org/10.2134/agronj2008.0218s

Irmak, S. (2009). Estimating Crop Evapotranspiration from Reference Evapotranspiration and Crop Coefficients. University of Nebraska-Lincol Web. Retrieved July 19, 2011, from http://extension.unl.edu/publications

Mhizha, T. (2010). Increase of yield stability by staggering the sowing dates of different varieties of rainfed maize in Zimbabwe (p. 166, PhD Thesis, Katholieke Universiteit Leuven, Belgium).

Mohamed, A. B., Duivenbooden, N. V., \& Abdoussallam, S. (2002). Impact of climatic change on agricultural Production in the Sahel. Climatic Change, 54, 327-348. https://doi.org/10.1023/A:1016189605188

Mpande, R. L., \& Twanda, M. (1998). Case study: Southern Africa population dynamics and the emerging competition for water use in the Zambezi river basin.

Phillips, J. G., Cane, M. A., \& Rosenzweig, C. (1998). ENSO, seasonal rainfall patterns and simulated maize yield variability in Zimbabwe. Agric. For. Meteorol., 90, 39-50. https://doi.org/10.1016/S0168-1923 (97)00095-6

Raes, D., Steduto, P., Hsiao, T. C., \& Fereres, E. (2009). AQUACROP—The FAO crop model to simulate yield response to water: II. Main algorithms and soft ware description. Agron. J., 101, 438-447. https://doi.org/10.2134/agronj2008.0140s

Ramirez-Villegas, J., Challinor, A. J., Thornton, K. P., \& Jarvis, A. (2013). Implications of regional improvement in global climate models for agricultural impact research. Environmental Research Letters, 8(2), 024018. https://doi.org/10.1088/1748-9326/8/2/024018 
Rinaldy, M., Losavio, N., \& Flagella, Z. (2003). Evaluation of OILCROP-SUN model for sunflower in southern Italy. Agricultural Systems, 78, 17-30. https://doi.org/10.1016/S0308-521X(03)00030-1

Steduto, P., Hsiao, T. C., Raes, D., \& Fereres, E. (2009). AQUACROP-The FAO crop model to simulate yield response to water: I. Concepts and underlying principles. Agron. J., 101, 426-437. https://doi.org/10.2134/ agronj2008.0139s

White, J. W., Hoogenboom, G., Kimball, B. A., \& Wall, G. W. (2011). Methodologies for simulating impacts of climate change on crop production. Field Crop Research, 124, 357-368. https://doi.org/10.1016/j.fcr.2011. 07.001

\section{Copyrights}

Copyright for this article is retained by the author(s), with first publication rights granted to the journal.

This is an open-access article distributed under the terms and conditions of the Creative Commons Attribution license (http://creativecommons.org/licenses/by/4.0/). 